\title{
Changes in the hypothalamus in relation to testicular cells during growth, maturation and spawning phases in the brackishwater teleost Liza parsia (Hamilton, 1822)
}

\author{
S. BOSE AND P. CHAKRABARTI* \\ Fisheries Laboratory, Department of Zoology, The University of Burdwan, Golapbag, Burdwan - 713104 \\ West Bengal, India \\ *Sreegopal Banerjee College, Bagati, Mogra, Hooghly - 712 148, West Bengal, India \\ e-mail:dr.pchakrabarti@yahoo.in
}

\begin{abstract}
In the present investigation, different cell types in the hypothalamus of the goldspot mullet Liza parsia (Hamilton, 1822) were characterised on the basis of their arrangement, distribution and tinctorial properties. The hypothalamic neurosecretory system of $L$. parsia is made up of two nuclei rich areas viz., nucleus pre-opticus (NPO), nucleus lateralis tuberis (NLT) and their axonal pathways. The NPO is vertically organised and the cells are arranged in an oblique plane on either side of the third ventricle. The larger cells viz., pars magnocellularis (PMC) are dorsally placed whereas smaller cells, pars parvocellularis (PPC) are placed ventrally to the third ventricle. Fine thread like axons stained with chrome-alum-haematoxylin-phloxine (CAHP) extend from preoptic cells to the close proximity of blood capillaries. Cells of the NLT are paired and situated above the pituitary gland. The cells of NPO and NLT exhibited both quantitative and qualitative variations during different periods of the testicular maturation. During growth and maturation periods, cells of PMC and NLT were characterised by intense staining and dense homogeneous granules along with deposition of neurosecretory materials. During spawning period, slight decrease in staining affinity of the cells of PMC and NLT were recorded. Changes in the testes of L. parsia have been described according to variations in gonadosomatic index (GSI) values and frequency percentages of different male germ cells during growth, maturation and spawning phases.
\end{abstract}

Keywords: Growth, Hypothalamus, Liza parsia, Maturation, Spawning phases, Testicular cells

\section{Introduction}

Hypothalamus in fish brain comprises groups of neurosecretory cells which mediate the endocrine responses of organisms via modulating the secretion of various releasing $(\mathrm{RH})$ as well as inhibiting hormones (IH) from the hypophysis (Goos et al., 1999; Lethimonier et al., 2004; Bano, 2012). Moreover, the complex acts as a mediator between the endocrine responses of organism and environmental changes (Ball, 1981). The feedback mechanism of the hypothalamus is modulated by various receptors sensitive to the excessive secretion of various hormones from different endocrine glands in vertebrates (Peter et al., 1991). In teleosts, the neurosecretory nuclei of the hypothalamus viz., nucleus pre-opticus (NPO) and nucleus lateralis tuberis (NLT) are the centers in the brain possibly responsible for secretion of gonadotropins in the hypophysis (Viswanathan and Sundararaj, 1974; Moitra and Medya, 1980; Maksimovich, 1987; Pandey and Peer Mohamed, 1997; Lal and Pandey, 1998; Gur et al., 2000).

Though gonads in teleosts have been subjected to numerous histological investigations, only a limited number of studies have been carried out on brackishwater teleost fishes. In depth studies on maturation cycles and changes in gonads of fish species are important in understanding and predicting annual changes in the population (Thorpe et al., 1990; Jobling et al., 2002; Tomkiewicz et al., 2003; Shein et al., 2004). Since hypothalamus of the brackishwater teleost Liza parsia is not yet studied properly; an attempt was made during the present study to delineate the morpho-histological architecture of the hypothalamo-neurosecretory centers in the speices as well as to find out the influence of the NPO and NLT nuclei on cytological changes in the testes during growth, maturation and spawning phases.

\section{Materials and methods}

Forty numbers of adult male specimens of L. parsia (15 - $20 \mathrm{~cm}$ in total length and $50-75 \mathrm{~g}$ in total body weight) were collected at fortnightly intervals during the study period during February 2010 to January 2014 from Junput brackishwater fish farm and estuarine region of Digha $\left(21^{\circ} 43^{\prime} 27.1^{\prime \prime} \mathrm{N} ; 87^{\circ} 49^{\prime} 17.5^{\prime \prime} \mathrm{E}\right)$, West Bengal 


\section{Gonadosomatic index (GSI)}

Data on total body weight and testes weight of 40 fishes were taken to calculate the mean gonadosomatic index (GSI) using the following formula:

$$
\text { GSI }=\frac{\text { Weight of testes }}{\text { Weight of fish }} \times 100
$$

\section{Histological methods}

To study the changes of the hypothalamic nuclei and testicular cells, the fishes were sacrificed and samples of brain with pituitary and testis were collected. The entire brain and pieces of testis sampled were fixed in aqueous Bouin's fixative for $18 \mathrm{~h}$. The tissues were then placed in $70 \%$ ethanol and subsequently dehydrated with ascending series of ethanol followed by acetone and cleared in benzene. Tissues were then embedded in paraffin (melting point $56-58^{\circ} \mathrm{C}$ ). The testis and mid-sagittal sections of the pituitary gland were cut at $4 \mu \mathrm{m}$ thickness using a Leica RM2125 RT microtome. Deparaffinised sections were rehydrated, brought to water and stained by various techniques viz., Delafield's Haematoxylin and Eosin (HE) for testis; Mallory's Triple stain (Mallory, 1936) for hypothalamus (MT) and testis; Chrome Alum Haematoxylin Phloxine (CAHP) (Gomori, 1941) for hypothalamus; Aldehyde fuchsin (AF) technique (Gabe, 1953) using orange green (OG) as counter stain for hypothalamus; Heidenhain's-Azan stain for hypothalamus; Lead hematoxylin phloxin stain for hypothalamus and Iron-alum haematoxylin for testis

After staining, the sections were dehydrated through ascending series of ethanol, cleared in xylene, mounted permanently with DPX and then examined under a binocular microscope. From the histological preparation of the hypothalamus, the diameter of various hypothalamic nuclei were measured using whippers micrometer. The total diameter of $\alpha$-cells, $\beta$-cells of NLT and PMC and PPC cells of NPO regions were measured under x1000 magnification. Diameter of various spermatogenic cells in testes was calculated with the help of reticulo-micrometer and ocular micrometer. The percentage of occurrence of different spermatogenic cells during different reproductive phases were measured and the measurements were made at four points within each cell at $90^{\circ}$ from one another and reported as mean \pm standard error of mean (SEM).

\section{Results}

\section{Hypothalamo-neurosecretory complex}

In L. parsia, the hypothamo-neurosecretory system consists of two nuclei rich areas viz., the nucleus preopticus (NPO), nucleus lateralis tuberis (NLT) and their axonal pathways. The NLT extends caudally as far as in a plane corresponding to the pituitary stalk. NPO is vertically organised in a broad and oblong area (Fig. 1a). The cells of the NPO exhibit considerable variations in staining intensity, morphological features and can be divided into two types viz., the dorsal pars magnocellularis (PMC) and the ventral pars parvocellularis (PPC) (Fig.1b). The NLT region is highly vascular and the cells of the NLT occupy a position above the pituitary gland in the lateral and latero-ventral wall of the hypothalamus (Fig. 1c). The cells of NLT may be of two types: the comparatively larger $\alpha$-cells which vary in size from 16.5 to $22.8 \mu$ having large sized nuclei generally in the range from 10.0 to $15.8 \mu$ in dia; the smaller $\beta$-cells which generally range from 8.2 to $10.8 \mu$. The cytoplasm showed presence of phloxinophilic secretory granules when stained with CAHP (Fig. 1d). The cells of the NPO are situated on either side of the third ventricle. Due to loose arrangement of the cells, the nuclei extend over a relatively larger area. The PMC was found to contain large neurosecretory cells measuring 16.8 to $25.5 \mu$ when stained with lead haematoxylin-phloxine and AF; and sometimes showed presence of beaded axons (Fig. 1e). When stained with CAHP and MT; PPC was found to be composed of smaller neurosecretory cells, measuring 8.5 to $10.6 \mu$ in length and 8.8 to $10.5 \mu$ in breadth (Fig. 1f).

\section{Testes}

In L. parsia, the testes are paired elongated structures situated ventrally to the kidneys and attached to the body wall of the mesenteries.

Gonadosomatic index (GSI): The GSI values varied from $0.33 \pm 0.06$ to $1.19 \pm 0.2$ during growth, maturation and spawning phases. However, the lowest value of the GSI $(0.33 \pm 0.06)$ was observed in June during the onset of growth phase. During July, August and September, the values increased to $0.37 \pm 0.14,0.42 \pm 0.09$ and $0.45 \pm 0.11$ respectively. From October onwards the testicular activity increased and the GSI values recorded in the maturation phase i.e., in October and November were $0.46 \pm 0.13$ and $0.86 \pm 0.14$ respectively. The mean GSI recorded during December was $1.08 \pm 0.06$ whereas in January this value dropped slightly to $0.98 \pm 0.17$. However, the highest GSI value of $1.19 \pm 0.2$ was recorded in the month of February (Fig. 2) owing to the proliferation of spermatozoa.

Sequential changes in the hypothalamic neurosecretory cells and spermatogenic cells during growth, maturation and spawning phases

The histological nature of the hypothalamic nuclei of L. parsia have been found to change synchronously with changes in the reproductive behaviour. 


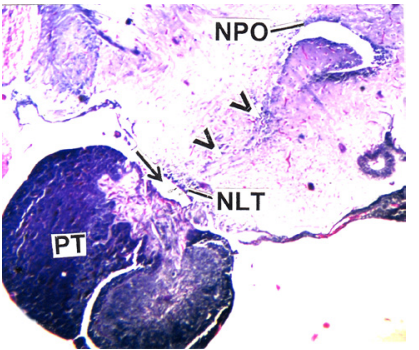

(a)

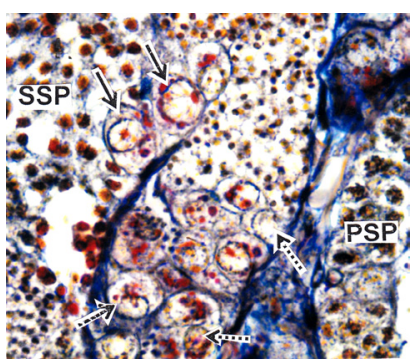

(e)

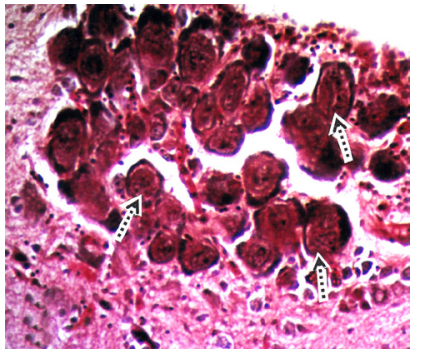

(i)

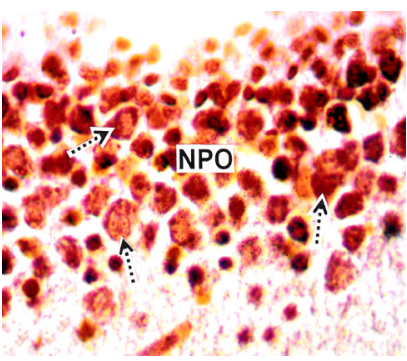

(m)
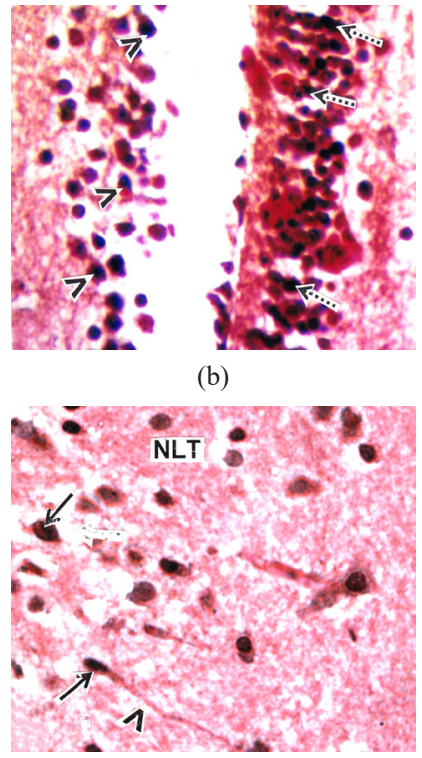

(f)

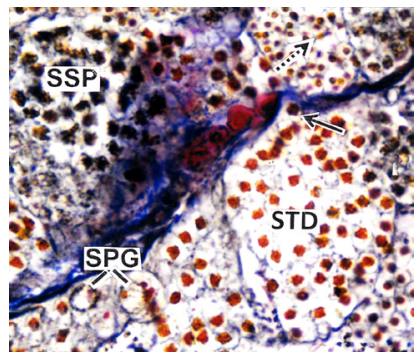

(j)

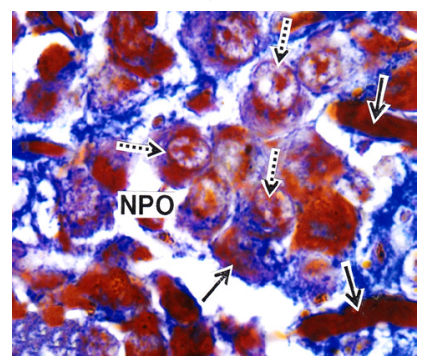

(n)

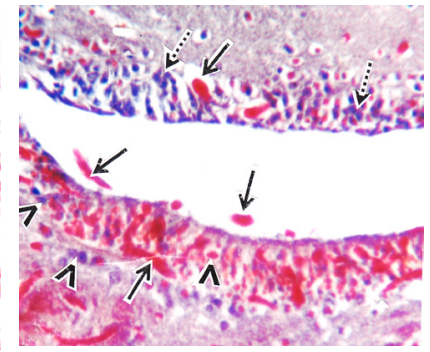

(c)

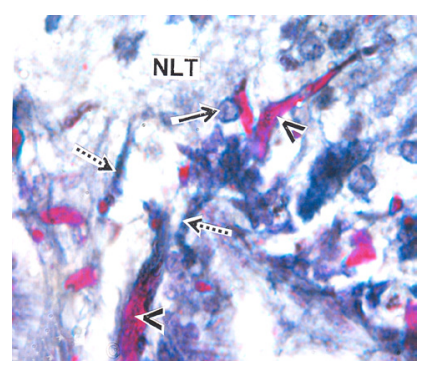

(g)

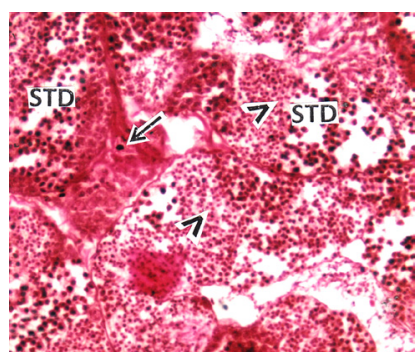

(k)

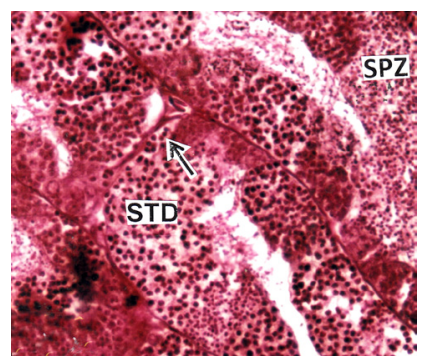

(o)

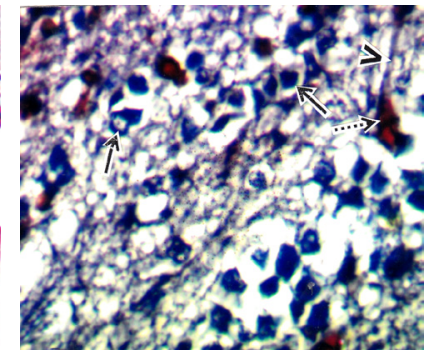

(d)

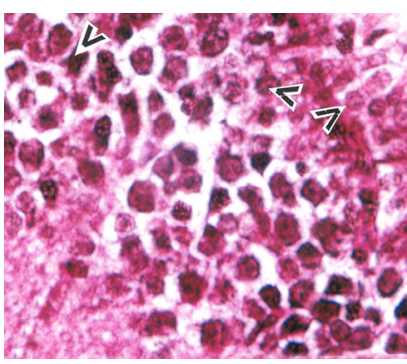

(h)

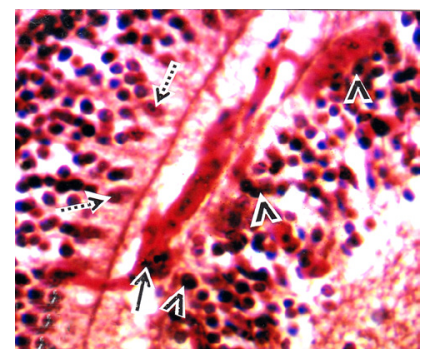

(1)

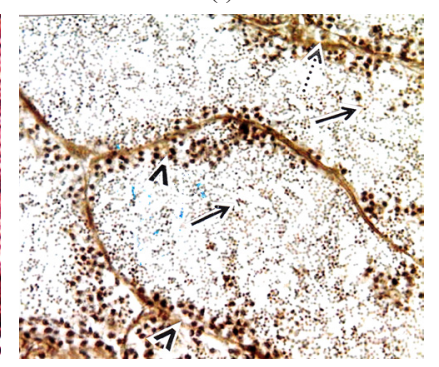

(p)

Figs. 1(a-p). Photomicrographs of sagital sections of hypothalamus of Liza parsia showing various cells in nucleus preopticus (NPO) and nucleus lateralis tuberis (NLT). [Chrome Alum Haematoxylin Phloxin: CAHP; Aldehyde fuchsin: AF; Lead Haematoxylin Phloxin; LHP: Mallory's triple; MT, Haematoxylin- eosin: HE; Heidenhain’s Azan : HA ; Iron Alum haematoxylin: IAH]

(a): NPO and NLT and their pathway (arrow heads). Note the axonal pathway of NLT entering pituitary gland (PT) (CAHP; $\times 50)$; (b): Binucleate or trinucleate cells of pars magnocellularis (PMC) (broken arrow) and pars parvocellularis (PPC) (arrow heads) of NPO during growth phase (AF; $\times 400)$; (c): $\alpha$-cells (broken arrows) and $\beta$-cells (arrow heads) of NLT with close association with neurosecretory materials (solid arrows) during growth phase (CAHP; $\times 400)$; (d): Arrangement of secretory cells of PPC (solid arrows). Note active secretory stage of PPC (broken arrows) along with neuron (arrow head) during growth phase (LHP; $\times 1000) ;(\mathrm{e})$ : Growth phase showing primary spermatogonia (PSPG) (solid arrows) and secondary spermatogonia (SSPG) (broken arrows). Note the presence of primary sprematocyte (PSP) having condensed nuclei and secondary spermatocyte (SSP) (MT; $\times 1000)$; (f): NLT cells (arrows) with long axon (arrow head) during maturation phase $(\mathrm{AF} ; \times 600)$; $(\mathrm{g})$ : Photomicrograph showing intimate association of NLT axons (broken arrows) and neurosecretory materials (NSM) (arrow heads) during maturation phase. Solid arrow indicates nucleus of NLT (LHP; $\times 600)$; (h): Hypertrophy of PPC (arrow heads) during maturation phase (AF; $\times 400)$; (i): Accumulation of NSM encircling the nucleus in hypertrophied PMC cells during maturation phase (AF; $\times 1000)$; (j): Proliferation of SSP and cysts of spermatid (STD). Note occurrence of spermatozoa (SPZ) (broken arrow) and reduction of SPG during maturation phase. Arrow indicates active interstitial cell (IC). (MT; $\times 600$ ); (k): Large number of SPZ (arrow heads) within the testicular lobule during maturation phase. Note cyst of STD and active IC (arrow) (HE; $\times 400$ ); (1): Enlargement of $\alpha$-cells (arrow heads) and $\beta$-cells (broken arrows) having intimate contact with NSM during spawning phase. Note intense accumulation of NSM in ventricle (solid arrow) (CAHP; $\times 400)$; (m): Active PPC cells (broken arrows) of NPO during spawning phase $(\mathrm{AF} ; \times 600)$; (n): Prominent nucleolus of active PMC (broken arrows) cells with NSM (solid arrows) during spawning phase $(\mathrm{HA} ; \times 1000)$; (o): Large number of SPZ in the lumen of the testicular lobules and cyst of STD during spawning phase. Arrow head indicates interstitial cell (HE; $\times 400)$; (p): Showing packed SPZ (solid arrows) in testicular lobules bordered by STD (arrow heads). Broken arrow indicates interstitial cells (IAH; $\times 400)$. 


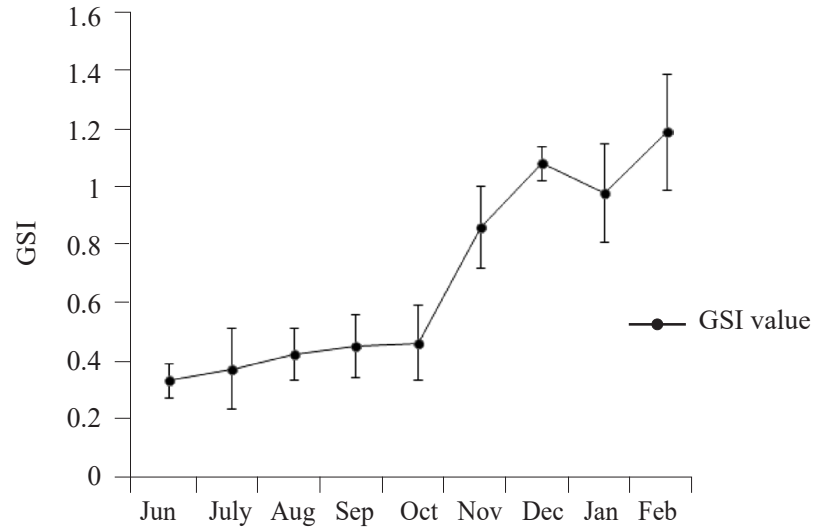

Fig. 2. Fluctuations in GSI of Liza parsia during growth, maturation and spawning phases

Growth phase (June to August): During the month of August, the neurosecretory materials (NSM) were found to be sparsely distributed in the cytoplasm and became less reactive to CAHP stain. During September, the NLT cells indicated a tendency to become active. The nucleus was found to contain intranuclear granules either arranged along the periphery of the nucleus or throughout the nuclear area (Fig. 1b). The intranuclear granules of the $\alpha$-cells begin to increase and NSM tends to accumulate around the nucleus. The staining intensity of the $\beta$-cells was also found to increase (Fig. 1b).

In L. parsia, the preoptic neurosecretory cells contain a nucleus and homogeneous mass of cytoplasm. Distinct visible change that occurred in the cytoplasm was the quantitative changes in the NSM in July (Fig. 1c). During July and August, the cells of the pars magnocellularis (PMC) (Fig. 1d) and the cells of the pars parvocellularis (PPC) increased characteristically in size with accumulation of large quantities of NSM granules around the nucleus and also with increase in staining intensity. Cells of the PMC attain a maximum size of 30 and $32.5 \mu$ whereas cells of the PPC attain maximum size of about 22 to $25 \mu$.

During June, the spermatogonia $(7.5 \times 5.6$ to $11.3 \times$ $8.2 \mu)$ are the predominant germ cells which lie arranged along the wall of the lobule. During July and August, spermatogonial cells undergo divisions and a gradual increase in the size of the seminiferous lobules takes place. Nest of secondary spermatogonia, primary spermatocytes and scattered secondary spermatocytes appear. Spermatids are most numerically abundant during end of August (Fig. $1 \mathrm{e})$.

Maturation phase (September to November): Cells of the NLT are active and the activity increase with progress of the stage. The intranuclear materials tend to accumulate around nucleus. Staining intensity of the cells increases and the NLT cells attain maximum size of approximately $30.5 \mu$ having prominent axon (Fig. 1f). During November, the cells attain a maximum size of approximately $41.5 \mu$ with prominent axon. At the end of November, the neurosecretory material in the cytoplasm begins to undergo depletion and the NLT cells become retractile (Fig. 1g).

During maturation phase, the PPC cells exhibit intense phloxinophilic materials filling the entire nucleus (Fig. 1h). Intramolecular phloxinophilic granules increase in PMC and the maximum accumulation occurs filling the entire nucleus (Fig. 1i).

During maturation phase, the spermatogonia decreases numerically and the secondary spermatocytes $(3.42 \times 4.23 \mu)$ occur in the form of cysts. The spermatids $(2.91 \times 3.87 \mu)$ are numerically most abundant during October (Fig. 1j). Spermatozoa $(1.93 \mu)$ formed by the transformation of spermatids appear abundantly in November (Fig. 1k). Interstitial cells are present at this stage which increase their staining intensity (Fig. 11). These cells become more prominent towards the end of November and range in length from 5 to $10 \mu$ and in breadth from 3.75 to $6 \mu$ (Fig. $1 \mathrm{~m}$ ).

Spawning phase (December to February): The NLT cells show maximum activity at this stage. Distinct axons bearing neurosecretory materials emerge from the NLT cells. These axons are in close association with the blood capillaries and sometimes the NLT cells are in direct contact with blood capillaries (Fig. 1n). During the end of this phase, the amount of neurosecretory materials in the NLT cells decreases due to active elaboration, thus the NLT cells become retractile and stain less intensely.

Due to the release of neurosecretory granules during the spawning period, the staining intensity of the PPC cells is less having vacuolisation (Fig. 1m). In the PMC, intranuclear granules are few and sparsely distributed. The nucleolus is prominent and the neurosecretory granules are almost depleted within the cytoplasm (Fig. 1o).

The seminiferous tubules attain maximum width at this stage. The tubules are packed with spermatozoa along with many cysts of spermatids (Fig. 1o). During January and February the tubules are uniformly packed with spermatozoa leaving cysts of spermatids along the periphery of the tubules (Fig. 1p). Maximum activity of the interstitial cells can be seen in this stage as they increase in number and size (Fig. 1o, p).

\section{Discussion}

The NPO in L. parsia was observed to be a broad and oblong region having inverted L shape, which is similar in line with the observations of Belsare (1975) in carps 
and Moitra and Medya (1980) in Cirrhinus mrigala. The NPO region of the L. parsia can be further divided into two differentiated zones, the pars magnocellularis (PMC) and pars parvocellularis (PPC). This finding goes in line with the observations of Belsare et al. (1970); Sundararaj and Viswanathan (1971) and Rizkalla (1976).

In L. parsia, the neurosecretory cells of the NPO region were found to stain positive with various stains like CAHP, AF and MT. Prakash et al. (1984) and Pandey (1993) have also reported similar staining property of the NPO neurosecretory cells in Notopterus chitala and Rastrelliger kanagurta respectively. The staining intensity, size and shape of the NPO cells correspond with the sexual maturity of the fish.

The PMC and PPC axons unite to form a common hypothalamo-hypophyseal tract downstream towards the hypophysis converging with the axonal tract of NLT region and finally enter into the pituitary via a neurohypophyseal stalk in L. parsia. This tract become more prominent during late maturation and early spawning periods compared to the growth phase due to the transport of large amount of NSM from NPO region providing a beads on string appearance under compound microscopy. Increased AF positive NSM globules are noted in the PMC and PPC regions. Similar observations have been made by Sundararaj and Viswanathan (1971); Rizkalla (1976); Moitra and Medya (1980) as well as Gur et al. (2000). In teleosts, the functional aspects of NPO cells are responsible to a large extent in the spawning activity and gonadal maturation by secreting neurosecretory materials (NSM) (Viswanathan and Sundararaj, 1974; Saxena, 1976; Tischenko et al., 1976; Zolotnitskiy, 1980; Prakash et al., 1984; Bano, 2012).

In L. parsia, the second most important neurosecretory centre of the hypothalamus is nucleus lateralis tuberis (NLT). It is a prominent structure and situated at a level just above the pituitary gland. This feature of NLT was also observed by various authors (Moitra and Medya, 1980; Maksimovich, 1987; Pandey, 1997). In contrary to this, there are various reports regarding the complete absence of NLT in some fishes (Saksena, 1979) although it has great implication on gonadal maturation. NLT cells are AF, CAHP and LH positive in nature and large globules of NSM can be observed during late maturation phase.

In the present study, during the growth phase, the neurosecretory cells of NPO and NLT were found to increase in size and NSM secretion from those cells started to exert effect in the GTH cells of the hypophysis leading to their increase in size and percentage. The intranuclear granules and concentration of NSM inside the neurosecretory nuclei of hypothalamus steadily increased during the maturation phase leading to increase in the activity of the gonadotrophs in the PPD region of the pituitary. During the spawning period, the neurosecretory granules are sparsely distributed in the NPO and NLT region with large number of vacuoles having less staining intensity due to the release of the NSM to the pituitary via neuro-hypophyseal tract which ultimately influence the GTH cells in synthesis of trophic hormone. Similar observation was also reported by Sinhababu et al. (2001) and Bano (2012).

The mature stage is seen during June and December, which reveals that spermiation occurs several times a year. The onset of spawning period is clearly marked by an increased activity in the conversion of spermatids to spermatozoa. The mature spermatozoa are released from the testes during spawning, but some residual spermatozoa are always left in the testis. The interstitial cells are found in small groups or singly in the interlobular spaces (Bara, 1969; Hyder, 1970) and these cells are supposed to produce reproductive steroid hormones. The ultrastructure of germ cells and the functions of Leydig and Sertoli cells associated with spermatogenesis in male Pampus argenteus were investigated by Chung et al. (2010). The Leydig cells, as typical steroidogenic cells having several cytoplasmic characteristics are actively involved in male steroidogenesis.

The findings of the present study on seasonal changes in the cells of hypothalamus in relation to testicular cells during growth, maturation and spawning phases in L. parsia provides an important basis for further investigation on the reproductive biology of this species and on its propagation in captivity.

\section{Acknowledgements}

The authors are grateful to Dr. Anandamoy Barik, Head, Department of Zoology, The University of Burdwan for providing laboratory facilities. The first author is thankful to the University Grants Commission, Eastern Regional Office, Kolkata for granting fellowship.

\section{References}

Ball, J. N. 1981. Hypothalamic control of the pars distalis in fishes, amphibians and reptiles. Gen. Comp. Endocrinol., 44: $135-170$.

Bano, Z. 2012. Correlative cyclical chances in the hypothalamoneurohypophysial system and gonads of a gar fish, Xenentodon cancila (Ham.). Bull. Env. Pharmacol. Life Sci., 1(12): 60-68.

Bara, G. 1969. Histochemical demonstration of the $3 \alpha, 3 \beta, 11 \beta$ and $17 \beta$ - hydroxysteroid dehydrogenases, in the testis of Fundulus heteroclitus. Gen. Comp. Endocrinol., 13: 189-200. 
Belsare, D. K. 1975. Morphological types of preopticoneurohypophyseal neurosecretory pathways in some teleosts. Z. Mikrosk. Anat. Forsch. Leipzig, 88(6): 1029-1035.

Belsare, D. K., Belsare, S. G. and Murthy, P. S. R. 1970. Hypothalamo-hypophyseal neurosecretory system in normal and hypophysectomised catfish, Clarias batrachus L. Acta Zool., 5: 219-228.

Chung, E. Y., Yang, Y. C., Kang, H. W., Choi, K. H., Jun, J. C. and Lee, K. Y. 2010. Ultrastructure of germ cells and the functions of leydig cells and sertoli cells associated with spermatogenesis in Pampus argenteus (Teleostei: Perciformes: Stromateidae). Zool. Stud., 49(1): 39-50.

Gabe, M. 1953. Sur quelquer application de la coloration par la fuchsin paraldehyde. Bulletin of Microscopic Application, 3: $153-162$.

Gomori, G. 1941. Observations with differential stains on human islets of Langerhans. American J. Pathol., 17: 395.

Goos, H. J., Senthikumaran, B. and Joy, K. P. 1999. Neuroendocrine integrative mechanisms in the control of gonadotrophin secretion in teleosts. In: Joy, K. P., Krishna, A. and Haider, C. (Eds.), Comparative endocrinology and reproduction. Narosa Publishing House, New Delhi, p. 113-136.

Gur, G., Melamed, P., Gissis, A. and Yaron, Z. 2000. Changes along the pituitary gonadal axis during maturation of the black carp, Mylopharyngodon piceus. J. Exp. Zool., 28: $13-40$.

Hyder, M. 1970. Histological studies on the testes of pond specimens of Tilapia nigra (Gunther) and their implication of the pituitary testis relationship. Gen. Comp. Endocrinol., 14: 198-211.

Jobling, S., Beresford, N., Nolan, M., Rodgers-Gray, T., Brighty, G. C., Sumpter, J. P. and Tyler, C. R. 2002. Altered sexual maturation and gamete production in wild roach (Rutilus rutilus) living in rivers that receive treated sewage effluents. Biol. Reprod., 66(2): 272-281.

Lal, K. K. and Pandey, A. K. 1998. Hypothalamoneurosecretory system of the female seabass, Lates calcarifer (Bloch), with special reference to gonadal maturation. Indian J. Fish., 45: 51-60.

Lethimonier, C., Madigou, T., Munoz-cueto, J. A., Lareyee, J. J. and Kah, O. 2004. Evolutionary aspects of GnRHs, GnRH neuronal systems and GnRH receptors in teleost fish. Gen. Comp. Endocrinol., 135: 1-16.

Maksimovich, A. A. 1987. Neurosecretory hypothalamohypophysial system of teleostean fish. J. Ichthyol., 27: 92-06.

Mallory, F. B. 1936. The aniline blue collagen stain. Stain Technology, 11: 101.

Moitra, S. K. and Medya, B. C. 1980. Histomorphology of the hypothalamo-neurohypophyseal system in relation to gonadal maturation in Cirrhinus mrigala, a freshwater Indian carp. Anat. Anz., 148: 409-421.

Pandey, A. K. 1997. Hypothalamo-neurosecretory system of the marine teleost, Megalaspis cordyla L. J. Mar. Biol. Ass. India, 39(1\&2): 132-135.

Pandey, A. K. 1993. Hypothalamo-neurosecretory system of the Indian mackerel, Rastrelliger kanagurta Cuvier. Nat. Acad. Sci. Lett., 16: 265-268.

Pandey, A. K. and Peer Mohamed, M. 1997. Hypothalamoneurosecretory system of the marine teleost, Sphyraena obtusata Cuvier. Indian J. Fish., 44(2): 191-200.

Peter, R. E., Trudeau, V. L. and Sloley, B. D. 1991. Brain regulation of reproduction in teleosts. Bull. Inst. Zool. Acad. Sinica (Mnnogr.), 16: 89-118.

Prakash, M. M., Shrivastava, S. S. and Balsare, D. K. 1984. Correlative cyclical changes in the hypothalamohypophysial-gonadal system in Notopterus chitala (Ham.). Z. Mikrosk-anat. Forsch., 98: 225-240.

Rizkalla, W. 1976. The hypothalamic neurosecretory system of the marine teleost fish, Mugil auratusrisso. Acta Biol. Academ. Scientia. Hungaricae, 27(2-3): 163-170.

Saksena, D. N. 1979. The hypothalamo-neurohypophysial system in Indian freshwater goby, Glossogobius giuris. Z. Mikrosk. Anat. Forsch., 93: 1137-1158.

Saxena, O. K. 1976. The hypothalamo-neurohypophysial system and its physiological relation to the reproductive cycle of Indian freshwater Goby. Glossogobius giuris. Acta. Physiol. Pol., 27(6): 539-548.

Shein, N. L., Chuda, H., Arakawa, T., Mizuno, K. and Soyano, K. 2004. Ovarian development and final oocyte maturation in cultured sevenband grouper Epinephelus septemfasciatus. Fish. Sci., 70(3): 360-365.

Sinhababu, D. P., Sarkar, S. K. and Choudhuri, D. K. 2001. Structure of hypothalamic nuclei, the nucleus lateralis tuberis (NLT) and its seasonal changes in relation to ovarian cycle of Labeo rohita. Indian J. Fish., 48(1): 9-16.

Sunderaraj, B. I. and Viswanathan, N. 1971. Hypothalamohypophysial neurosecretory and vascular systems in the catfish, Heteropneustes fossilis (Bloch). J. Comp. Neurol., 141: 95-196.

Thorpe, J. E., Talbot, C., Miles, M. S. and Keay, D. S. 1990 Control of maturation in cultured Atlantic salmon, Salmo salar in pumped seawater tanks, by restricting food intake. Aquaculture, 86: 315-326.

Tischenko, N. T., Yorisova, M. N. and Polenov, A. L. 1976. The preoptico-hypophysial neurosecretory system in the Baikal teleost, Coregonus autumnalis migmtorius during the prespawning period. Z. Evol. Biochem. Fisiol. (Moskova), 12: $439-443$

Tomkiewicz, J., Tybjerg, L. and Jespersen, A. 2003. Micro-and macroscopic characteristics to stage gonadal maturation of female Baltic cod. J. Fish Biol., 62(2): 253-275. 
Viswanathan, N. and Sundararaj, B. I. 1974. Seasonal changes in the hypothalamo-hypophyseal-ovarian system in the catfish, Heteropneustes fossilis (Bloch). J. Fish Biol., 6(3): 331-340.
Zolotnitskiy, A. P. 1980. The morphofunctional characteristics of the hypothalamo-hypophysial neurosecretory system of the Black Sea turbot, Scophthalamus maeoticus, in connection with reproductive cycle. J. Ichthyol., 20: 104-111. 